\title{
低温殺菌牛乳と超高温殺菌牛乳の物性および風味特性
}

\author{
高木 和子，依田一豊，宮澤 賢司，原田 岳，何 方，平松 優 \\ タカナシ乳業株式会社 商品研究所
}

\section{Physicochemical properties and sensory attributes of LTLT milk and UHT milk}

\author{
Kazuko Takagi, Kazutoyo Yoda, Kenji Miyazawa, Gaku Harata, \\ Fang He, Masaru HiRAmatsu \\ Technical Research Laboratory, Takanashi Milk Products Co., Ltd.
}

\begin{abstract}
In this study, we compared the physicochemical properties and sensory attributes of low temperature pasteurized (LTLT) milk and ultra-high temperature treated (UHT) milk, both of which were produced using the same raw milk. The consumer tests indicated that the odor, sweetness, thickness, and after-taste were weaker in the LTLT milk compared to that in the UHT milk $(p<0.01)$ and that the LTLT milk was more refreshing than the UHT milk $(p<0.01)$. Although the taste of UHT milk was more familiar than that of the LTLT milk $(p<0.05)$, there was no difference in palatability of the two milks. The odor of the LTLT milk resembled that of raw milk when the odor was analyzed at $40^{\circ} \mathrm{C}, 50^{\circ} \mathrm{C}$, and $60^{\circ} \mathrm{C}$ by using an odor sensor. However, the odor of UHT milk was different from that of both the LTLT milk and the raw milk. The viscosity of the LTLT milk was lower than that of the UHT milk $(p<0.05)$. The hardness of custard puddings prepared using LTLT milk was lesser than that of custard puddings prepared using UHT milk $(p<0.01)$. In addition, the sensory evaluation with the expert panel indicated that the custard pudding prepared using LTLT milk was softer and had a better melting feeling in the mouth compared with that prepared using UHT milk $(p<0.01)$.
\end{abstract}

(Received 15 September 2015, Accepted 20 January 2016)

Keywords: LTLT milk 低温殺菌牛乳, UHT milk 超高温殺菌牛乳, WPNI (Whey Protein Nitrogen Index) ホエイタンパク指数, odor におい, custard pudding カスタードプリン, sensory evaluation 官能評価

\section{1. 緒言}

牛乳は, 栄養バランスの優れた身近な食品として知 られ, 衛生的な安全性確保のため加熱殺菌処理が施さ れる，日本では，食品衛生法に基づく「乳㧍よび乳製 品の成分規格等に関する省令」により加熱殺菌する ことが規定されている．加熱殺菌の方法には，120〜 $150^{\circ} \mathrm{C}$ の超高温で 1 3 秒間殺菌する「超高温瞬間殺 菌」, $63 \sim 68^{\circ} \mathrm{C}$ で長時間（30 分間）殺菌する「低温殺 菌」, $72^{\circ} \mathrm{C}$ 以上で 15 秒間以上殺菌する「高温短時間 殺菌」などがある（社団法人日本乳業協会, 2014）.

著者連絡先 k-yoda@takanashi-milk.co.jp
加熱殺菌の温度や時間は, 牛乳の風味に大きく影 響することが知られている（岩附ら，1999a；岩附ら， 1999b ; 荒井と玉木, 2008). その原因の一つとして, ホエイタンパク質が加熱変性し, 加熱臭と呼ばれる風 味変化を起こすことが挙げられる. そのため, 低温殺 菌や高温短時間殺菌された牛乳では, 超高温瞬間殺菌 されたものよりホエイタンパク質の熱変性度合いが少 なく, 加熱臭も少ない。 また, 国内で市販されている 牛乳の 9 割以上は超高温瞬間殺菌牛乳 (超高温殺菌牛 乳）であり（社団法人日本乳業協会, 2014), 日本人 には加熱臭のする超高温殺菌牛乳のほうが飲み慣れた ものとして好まれる傾向にあることが報告されてい 
る（岩附ら, 1999a)。一方で, 牛乳の風味は集乳地域 や季節によっても大きく変化するため, 市販牛乳を用 いて殺菌温度による風味の評価を行うには，これらを 考慮する必要がある，岩附ら（1999a）の市販牛乳を 用いた風味評価では, 供試された超高温殺菌牛乳や低 温殺菌牛乳などに使用された生乳の由来は明らかでな い. また， 2003 年に実施された市販牛乳の調査では, 七種類の低温殺菌牛乳のうちタンパク質の熱変性の高 いものが検出されている（独立行政法人国民生活セン ター, 2003).

そこで, 本研究では同地域で同日に集乳された生乳 を用いて同一工場で製造された市販の成分無調整牛乳 を比較することで, 生乳の由来や製造要因による誤差 を減らし, 殺菌方法による牛乳の物性や風味の違いを 調査した，さらに，調理品に対する影響を調べるため, 異なる殺菌方法の牛乳を素材としたカスタードプリン のテクスチャーについて調査した.

\section{2. 実験方法}

\section{2-1. 実験試料}

本研究では, 岩手県葛巻地域で集乳された生乳を用 いて, タカナシ乳業株式会社の同一工場で製造された 市販の低温殺菌牛乳および超高温殺菌牛乳を使用し た. 低温殺菌牛乳は連続式低温殺菌法で $66^{\circ} \mathrm{C} 30$ 分間, 超高温殺菌牛乳は $130^{\circ} \mathrm{C} 2$ 秒間, 両牛乳ともに間接加 熱法によって殺菌された。 また, 乳脂肪分 $3.6 \%$ 以上, 無脂乳固形分 $8.4 \%$ 以上を規格とし，ホモジナイズさ れた成分無調製牛乳であった。 各試験では同日に集乳 された生乳で製造されたものを比較し，異なる集乳日 の生乳で製造された牛乳製品間の比較をした場合には, 各試験項目にその旨を記載した。

\section{2-2. 実験方法}

\section{1）未変性ホエイタンパク質の測定}

牛乳中の未変性ホエイタンパク質量を測定するため, Leighton（1962）の方法に準じてホエイタンパク指数 (WPNI: Whey Protein Nitrogen Index) を求めた. 試料 $20 \mathrm{ml}$ に塩化ナトリウム $8 \mathrm{~g}$ を添加した後, 万過し，万 液 $1 \mathrm{ml}$ を $0.05 \mathrm{M}$ フタル酸水素カリウム/飽和食塩水 $10 \mathrm{ml}$ に加え, $420 \mathrm{~nm}$ での透過率を測定し, あらかじ めケルダール法で作成しておいた標準曲線より WPNI を算出した、試料は, 異なる 4 集乳日の生乳から製造 されたものを使用した。

\section{2）一般消費者による牛乳の風味比較}

一般消費者として大学生 27 名（男性 6 名, 女性 21
名）をパネルとし，記号化した二種類の牛乳 $\left(10^{\circ} \mathrm{C}\right)$ をプラスチック容器に注いで供試し，7段階評点法で 評価させた．評価項目は「においの強さ」「においの 好み」「すっきり感」「甘味の強さ」「甘味の好み」「濃 厚感」「後味の強さ」「後味の好み」「飲み慣れた味」「総 合評価（好み）」の 10 項目とした，また，においにつ いては, 口に含んだ祭に鼻に抜けるにおいについて評 価した。

\section{3）においセンサーによるにおい比較}

に抢いセンサー（に扔い識別センサーシステム $\alpha$ FOX3000 Alpha M.O.S. フランス) を用いて, 二種類 の牛乳㧍よびこれらの製造に使用された生乳のにおい を測定した。測定温度は $40^{\circ} \mathrm{C}, 50^{\circ} \mathrm{C}$, および $60^{\circ} \mathrm{C} て ゙$, 同一試料を 3 回ずつ測定した。

\section{4）粘度測定}

音叉型振動式粘度計（SV-10, 株式会社エー・アン ド・ディ）を用い， $10^{\circ} \mathrm{C}$ で測定した。試料は，異な る3 集乳日の生乳で製造された低温殺菌牛乳および超 高温殺菌牛乳を使用した。

\section{5） カスタードプリンのテクスチャーへの影響}

牛乳を素材とする調理品への影響を確認するため, 二種類の牛乳を用いてカスタードプリンを調製し, 分 析パネルによるテクスチャー比較掞よびクリープメー ターによる硬さ（最大荷重）の測定を行った. カス タードプリンの調製方法は下記に示した.

\section{(1)材料}

牛乳は, 低温殺菌牛乳および超高温殺菌牛乳を使用 した，そのほかの材料には, 市販鵎卵, グラニュー糖 (パールエース印 株式会社パールエース $\mathrm{E}$ ), バニラ エッセンス（クラウンフーヅ株式会社）を使用した.

(2)配合

調製試料は, 牛乳 $500 \mathrm{~g}$ (低温殺菌牛乳または超高

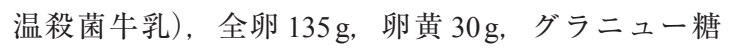
$100 \mathrm{~g}$ ，バニラエッセンス $0.45 \mathrm{ml}$ とした.

(3)調製方法

全卵，卵黄，グラニュー糖を混ぜたものに， $60^{\circ} \mathrm{C}$ に温めた牛乳を少しずつ加え混ぜた後, 金属メッシュ

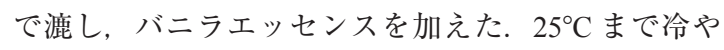
した後, プリン型（底面直径 $60 \mathrm{~mm}$, 上面直径 $80 \mathrm{~mm}$, 高さ $35 \mathrm{~mm})$ に $65 \mathrm{~g}$ 注ぎ, 天板に並べた.また, 上 面にも天板を載せて覆った，天板にプリン型の高さの $3 / 4$ の位置まで $60^{\circ} \mathrm{C}$ のお湯を張り, オーブン（KS6-2-4, 櫛澤電気製作所）で $160^{\circ} \mathrm{C}, 60$ 分間加熱した。 プリン が固まった後, オーブンから取り出し室温で 1 時間放 
日本官能評価学会誌 Vol. 20 No. 1

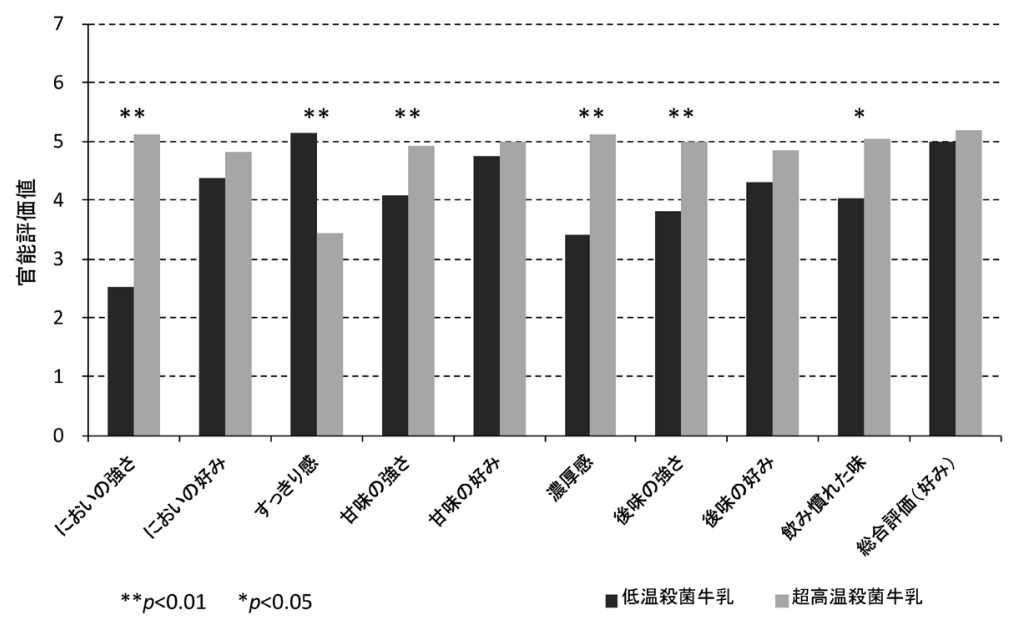

Figure 1 牛乳の風味比較 (平均值)

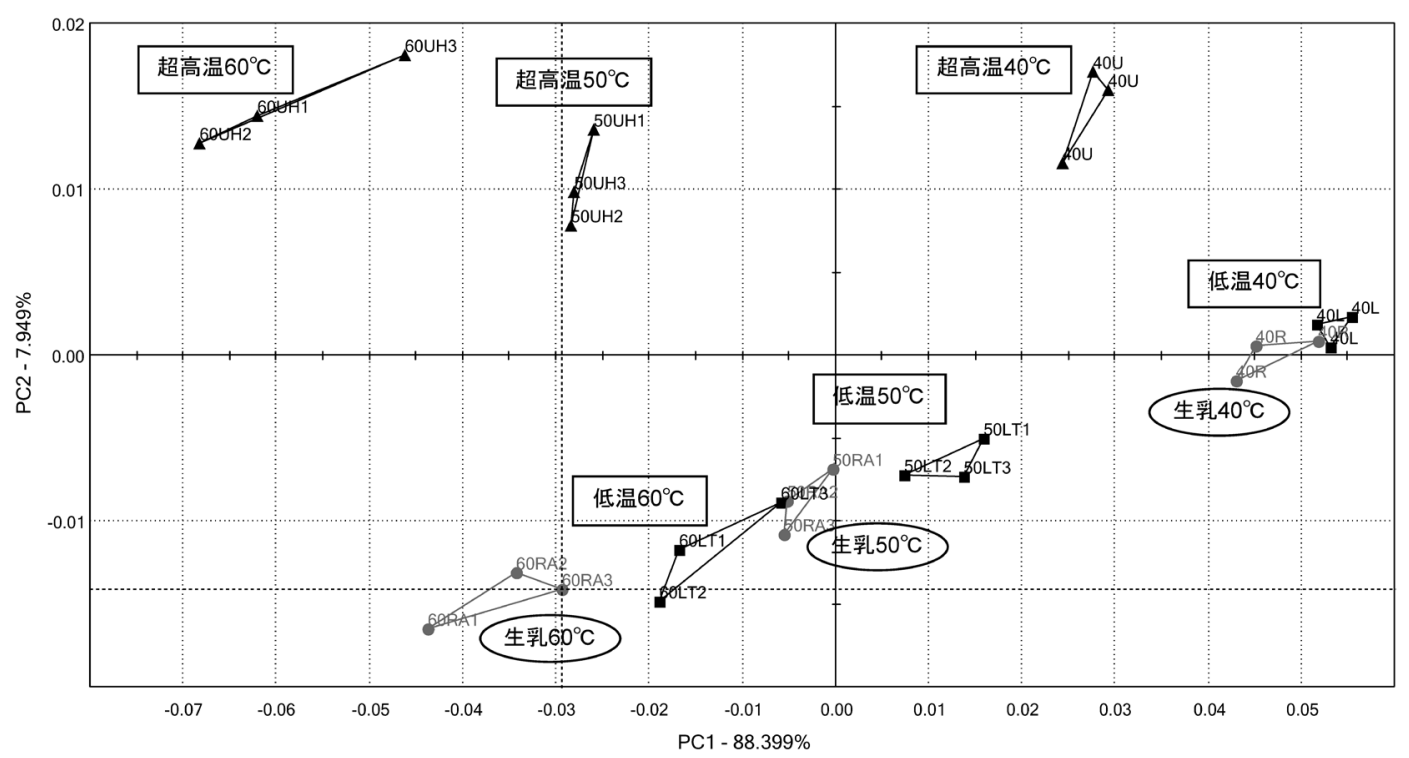

Figure $240^{\circ} \mathrm{C}, 50^{\circ} \mathrm{C}, 60^{\circ} \mathrm{C}$ 牛乳のにおいセンサー結果

置して粗熱をとった，その後，ラップをかけて $10^{\circ} \mathrm{C}$ で 20 時間保存し，下記の試験を実施した。

\section{A. 官能評価によるテクスチャーの比較}

タカナシ乳業社員の分析型官能パネル 12 名（男性 6 名, 女性 6 名）により, 記号化した 2 種類のプリン を7段階評点法で評価した。評価項目は,「口溶け」 「硬さ」「もっちり感」とした。

B. クリープメーターによる硬さの測定

調製したカスタードプリンの硬さをクリープメー ター（RE-33005, 株式会社山電）で測定した. 測定
方法は, プリンをカップに入れた状態で直径 $16 \mathrm{~mm}$ の円柱型プランジャーを圧縮速度 $1 \mathrm{~mm} / \mathrm{sec}$, 圧縮率 $67 \%$ で進入させ測定した。

\section{6) 統計処理}

低温殺菌牛乳と超高温殺菌牛乳の 2 群間の有意差 検定は, Studentの $t$ 検定で行った. 解析ソフトは JMP10（SAS Institute Inc., アメリカ）を用いた. 


\section{3. 実験結果}

1）市販牛乳中の未変性ホエイタンパク質の比較

供試した市販牛乳製品の加熱変性度合いを確認す るため, 異なる 4 集乳日の生乳から製造された二種 類の牛乳の WPNI を求めた (各群 $n=4)$. 低温殺菌 牛乳では $6.93 \pm 0.38 \mathrm{mg} / \mathrm{ml}$, 超高温殺菌牛乳では 0.70 $\pm 0.05 \mathrm{mg} / \mathrm{ml}$ であり, 低温殺菌牛乳のほうが有意に未 変性ホエイタンパク質 $(p<0.01)$ を多く含んでいた また, 生乳の WPNI は $7.85 \pm 0.36 \mathrm{mg} / \mathrm{ml}$ であった。

\section{2）一般消費者による牛乳の風味比較}

二種類の市販牛乳製品に対する一般消費者によ る官能評価結果を Figure 1 に示した。 低温殺菌牛乳 は, 超高温殺菌牛乳に比べ「すっきり感」が有意に強 く $(p<0.01)$,「においの強さ」「甘味の強さ」「濃厚 感」「後味の強さ」が有意に弱かった $(p<0.01)$. また, 「飲み慣れた味」では超高温殺菌牛乳が有意に選ばれ

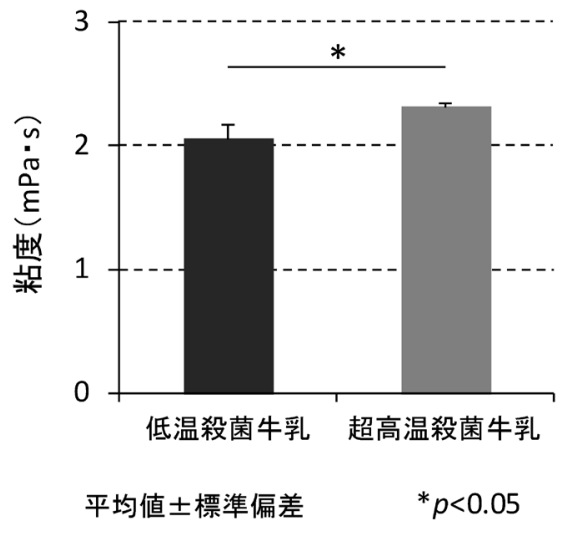

Figure 3 牛乳の粘度

(A)

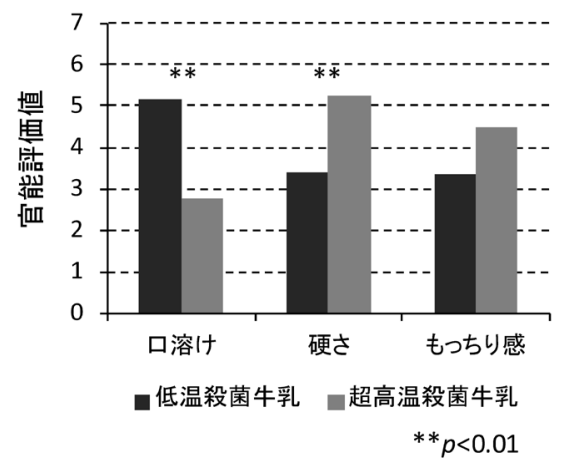

た $(p<0.05)$.しかし，「においの好み」「甘味の好み」 「後味の好み」「総合評価 (好み)」について有意差は なかった.

\section{3）においセンサーによるにおい比較}

12 個のセンサーデー夕を主成分分析した結果を Figure 2 に示した. $40^{\circ} \mathrm{C}$ でのに抒いは, 低温殺菌牛乳 と生乳が近く, 超高温殺菌牛乳はやや離れたポイント に位置した，温度の上昇に伴ってにおいの質は徐々に 変化したが, その挙動は低温殺菌牛乳と生乳が近く, 低温殺菌牛乳と超高温殺菌牛乳の差は大きくなった。

\section{4) 粘度の比較}

二種類の牛乳製品の粘度測定結果を Figure 3 に示 した，低温殺菌牛乳の粘度は $2.06 \pm 0.12 \mathrm{mPa} \cdot \mathrm{s}$, 超高 温殺菌牛乳の粘度は $2.31 \pm 0.04 \mathrm{mPa} \cdot \mathrm{s}$ で (各群 $n=9$ ), 低温殺菌牛乳のほうが超高温殺菌牛乳と比較して有意 に粘度が低かった $(p<0.05)$.

5） カスタードプリンのテクスチャーに対する影 響

二種類の牛乳で調製したカスタードプリンに対する 分析型官能パネル 12 名の7段階評点法による評価結 果を Figure 4A に示した.「硬さ」は, 低温殺菌牛乳 で調製したプリンのほうが有意に軟らかいと評価され た $(p<0.01)$.また, 「口溶け」については, 低温殺 菌牛乳で調製したプリンに扔いて有意に口溶けがよい と評価された $(p<0.01)$.「もっちり感」については 有意差がなかった，次に，官能評価に使用したプリ ンの硬さをクリープメーターで測定した結果を Figure $4 \mathrm{~B}$ に示した。低温殺菌牛乳で調製したプリンの硬さ は, 超高温殺菌牛乳で調製したものより有意に軟ら かかった $(p<0.01)$ 。また, 異なる 3 集乳日の生乳由

(B)

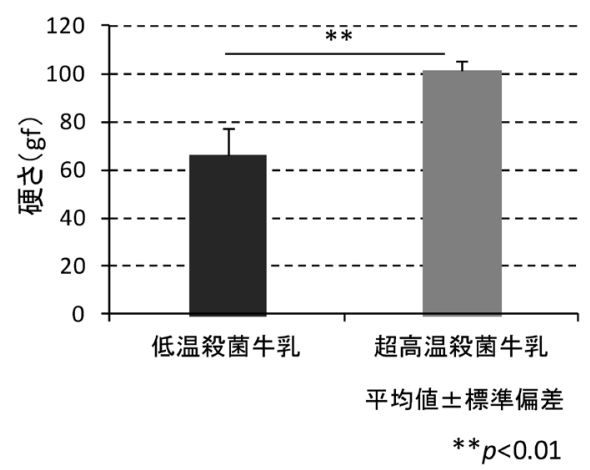

Figure 4 カスタードプリンの官能評価によるテクスチャー (A) および物性測定による硬さ $(\mathrm{B})$ の比較 
来の牛乳製品で調製されたカスタードプリンの硬さは,

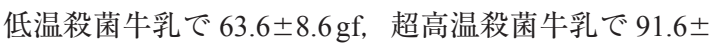
$12.2 \mathrm{gf}($ 各群 $n=12$ ) であり, 低温殺菌牛乳で調製し たプリンが有意に軟らかくなることが明らかとなった $(p<0.01)$.

\section{4. 考察}

国内における低温殺菌牛乳の流通量は少なく, 同じ 生乳由来で, かつ市販されている低温殺菌牛乳と超高 温殺菌牛乳を比較した研究報告は見当たらない. 独立 行政法人国民生活センター（2003）による調査では市 販の低温殺菌牛乳製品の中には, 未変性ホエイタンパ ク質含量が少なく, 熱履歴が高いと推測される製品が あることが報告されている。そこで本研究を実施する にあたり，使用する牛乳製品の未変性ホエイタンパク 質量を調査し, 研究に使用するサンプルとして適当か どうかを確認した. Renner（1979）は，間接加熱法で 殺菌された牛乳の場合, 低温殺菌牛乳ではホエイタン パク質の変性率が 7〜21\%, 超高温殺菌牛乳では 70〜 $93 \%$ であことを報告している. 本研究では, 低温殺 菌牛乳で $11.8 \pm 4.8 \%$, 超高温殺菌牛乳で $91.1 \pm 0.6 \%$ となり, 過去に報告されている低温殺菌牛乳および超 高温殺菌牛乳と同等の特性を持つと考えられた.

牛乳は $80^{\circ} \mathrm{C}$ 以上で殺菌された場合に加熱臭が生成 され (上野川ら, 2009), 超高温殺菌牛乳は低温殺菌 牛乳より香気成分の種類や量が多いことが報告されて いる（岩附ら，1999b）。本研究の一般消費者による官 能評価でも「においの強さ」は超高温殺菌牛乳で有意 に高かった。一方で,「においの好み」について差は 見られず，岩附ら（1999a）の一般消費者および専門 パネルによる評価と異なる結果となった. その理由と して, 専門パネルに比べて一般消費者では加熱による においの変化が好みに影響しておらず，また上記の報 告では一般消費者によって評価された製品の生乳の由 来が異なることも考えられ, 一般消費者にとっては加 熱によるにおいより, 生乳由来のにおいのほうが好み に影響している可能性が考えられた。 さらに，におい センサーを用いたにおいの質の比較では, 二種類の牛 乳の間に大きな差があった. 特に, 測定時の温度を $40^{\circ} \mathrm{C}$ から $50^{\circ} \mathrm{C}, 60^{\circ} \mathrm{C}$ へ上げた際にこの差はより大 きくなった。一般的に高温のほうが揮発する成分が多 くなるため, 香気成分を多く含む超高温殺菌牛乳では より多くのにおいが測定され, 差が大きくなった可能 性が考えられる。また, $60^{\circ} \mathrm{C}$ 程度の温度はホットミ
ルクとして飲用する温度帯であり，ホットミルクにし た場合にはヒトが二種類の牛乳のにおいの違いをより 感じやすくなる可能性が示唆された. 今後, ホットミ ルクを用いた官能評価も実施する必要があると考えら れた。一方で, 本試験では低温殺菌牛乳と生乳のにお いは近く，測定温度による変化の挙動も近かった．生 乳のにおいが自然なにおいと考えた場合, 低温殺菌牛 乳はよりナチュラルなにおいを維持していると考えら れた。

低温殺菌牛乳は超高温殺菌牛乳よりさっぱりしてお り，また超高温殺菌牛乳のほうが風味に慣れているこ とから好まれるという評価が報告されている（岩附ら， 1999a)。本研究においても, 低温殺菌牛乳は「すっき り感」が強く,「甘味の強さ」「濃厚感」「後味の強さ」 が弱く, 超高温殺菌牛乳は「飲み慣れた味」と評価さ れ, 上記報告と一致していた。一方で嗜好に関する項 目では, いずれも二種類の牛乳の間に有意差は見られ なかった。これらの結果は, 一般消費者が両牛乳の風 味を感じとり差別化し, 超高温殺菌牛乳を飲み慣れた 味として認識しているものの, 好みは二分しているこ とを示唆する。 また, 最近の牛乳・乳製品の消費者動 向調査（独立行政法人農畜産業振興機構, 2015) によ ると, 消費者の牛乳風味に対する不満点は,「牛乳は 味にクセがある」「牛乳のにおいが嫌い」「牛乳は飲ん だあと口に残る」ことが報告されている．本研究の官 能評価では，低温殺菌牛乳はすっきり感が強く，にお いや後味の少ない牛乳と評価されており, 消費者の不 満に応える牛乳であることが示唆された. また, 過去 の報告と比較して嗜好に差が見られなかったのは, 時 代による消費者の嗜好の変化もあるかもしれない.

低温殺菌牛乳の風味評価において, 超高温殺菌牛乳 より粘性が低く感じることが報告されている（岩附 ら，1999a). 本研究では物理的粘度を測定したところ, 超高温殺菌牛乳と比較して低温殺菌牛乳で有意に粘度 が低かった．牛乳の殺菌と粘度に関する研究は, 1800 年代後半〜 1900 年代前半に多く実施されており, 低 温殺菌の温度である $60^{\circ} \mathrm{C}$ 近辺までの温度では粘度が 低下し，75〜 $80^{\circ} \mathrm{C}$ では粘度が上昇する（Bateman \& Sharp, 1928; Evenson \& Ferris, 1924). また, 加熱によ る粘度の上昇は, $\beta$-ラクトグロブリンの加熱変性とそ れに伴うカゼインミセルへの結合によるところが大 きい（McCarthy, 2011）。そのほかにも牛乳の粘度に影 響する要因として乳脂肪やホモジナイゼーションな どが知られているが（Bakshi \& Smith, 1984; McCarthy, 
2011), 本研究では同一の生乳が用いられ, ホモジナ イズされた製品を使用していることから，これらの要 因よりむしろホエイタンパク質の加熱変性が粘度に大 きく影響していると考えられた。 そして，この粘度の 違いをヒトが敏感に感じ取り, 低温殺菌牛乳を「すっ きり」「さっぱり」と感じていることが考えられる.

また，二種類の牛乳でカスタードプリンを調製した 際に，官能パネルによる評価だけでなくクリープメー ターによる物理的な硬さ測定によっても, 低温殺菌牛 乳で調製したカスタードプリンにおいて有意にテクス チャーが軟らかいことが示された．ホエイタンパク 質の加熱によるゲル化や凝集を考慮すれば（Bromley et al., 2005), 二種類の牛乳中における未変性ホエイ夕 ンパク質含量の違いが, 調製時の加熱過程におけるプ リンのゲル化に大きく影響していることが考えられた. これらメカニズムの調査は今後の検討課題である.

近年, 日本では牛乳の飲用頻度が減少しており, 飲 用以外の牛乳利用を普及させることも, 国内の酪農政 策の観点から重要な課題である. 市販飲用牛乳の物性 や風味特徵を把握し消費者に公開することは, 牛乳 利用の幅を広げることにつながるだろう。たとえば, チーズ作りのような生乳に近い特徵を持つ牛乳を使用 したいユーザーにとっては, 低温殺菌牛乳は一つの選 択肢となるだろう。また, 本研究の結果は, 牛乳それ ぞれの特徴を活かすことで, 添加物などを使用せずに 料理や菓子に物性の変化をもたらすことができること を示している。 このように低温殺菌牛乳と超高温殺菌 牛乳の特徴やアプリケーションを明らかにしていくこ とで, それぞれの牛乳に利用価值が付加され, 牛乳利 用の促進につながると考える.

\section{引用文献}

荒井威吉，玉木民子（2008）牛乳に対する消費者の嗜 好における最近の評価傾向, 新潟青陵短期大学 部研究報告会, 38, 25-32.

Bakshi, A.S. and Smith, D.E. (1984) Effect of fat content and temperature on viscosity in relation to pumping requirements of fluid milk products, Journal of Dairy Science, 67(6), 1157-1160.

Bateman, G.M. and Sharp, P.F. (1928) A study of the apparent viscosity of milk as influenced by some physical factors, Journal of Agricultural Research, 30, 647-674.

Bromley, E.H., Krebs, M.R. and Donald, A.M. (2005) Aggregation across the length-scales in betalactoglobulin, Faraday Discussions, 128, 13-27.

独立行政法人国民生活センター（2003）牛乳の品質 と衛生一殺菌タイプ別の特徴を中心に一, http:// www.kokusen.go.jp/pdf/n-20031003_1.pdf

独立行政法人農畜産業振興機構 (2015) 最近の牛乳 · 乳製品の消費者動向調査, https://www.alic.go.jp/ joho-c/joho05_000026.html（2015 年 8 月 15 日）

Evenson, O.L. and Ferris, L.W. (1924) The viscosity of natural and remade milk, Journal of Dairy Science, 7(2), 174-188.

岩附慧二, 溝田泰達, 住正 宏, 外山一吉, 冨田 守 （1999a）牛乳の官能特性に及ぼす殺菌条件の影 響, 日本食品科学工学会誌, 46 (8), 535-542.

岩附慧二, 溝田泰達, 久保田哲夫, 西村 修, 増田秀 樹, 外山一吉, 冨田 守 (1999b) Aroma Extract Dilution Analysis による殺菌牛乳の香気評価, 日 本食品科学工学会誌, 46(9), 587-597.

上野川修一, 清水 誠, 堂迫俊一, 鈴木英毅, 元島英 雅, 高瀬光徳 (2009) 『ミルクの事典』, 朝倉書店, 東京, p. $11,19,58,60$.

Leighton, F.R. (1962) Determination of whey protein index of Dairy skim milk powder, The Australian Journal of Technology, 17(4), 186-188.

McCarthy, O.J. (2011) Rheology of liquid and semi-solid milk products, Encyclopedia of Dairy Sciences, 2nd edition, vol. 4, Academic Press, San Diego, CA, USA, pp. 520-531.

社団法人日本乳業協会（2014）日本乳業年鑑 2014 年 度版 (資料編).

Renner, E. (1979) Nutritional and biochemical characteristics of UHT milk, Proceedings International Conference on UHT Processing and Aseptic Packaging of Milk and Milk Products, Chemical, Nutritional \& physical properties, November 27-29, pp. 21-52. 